\title{
Civic Virtue Development in Social and Economic Fields Through Social Entrepreneurship
}

\author{
Rina Susanti ${ }^{1, *}$, Karim Suryadi ${ }^{2}$ \\ ${ }^{1,2}$ Universitas Pendidikan Indonesia, Bandung, Indonesia \\ ${ }^{*}$ Corresponding author. Email: rinasusanti@upi.edu
}

\begin{abstract}
The purpose of this study is to examine efforts to foster civic virtue in the social and economic fields through social entrepreneurship. This study uses a qualitative approach with a systematic literature review (SLR) study method. Sources of information collected in this paper were obtained from various sources both online and offline in the from of books, journals, proceedings, dissertations, government regulations, and other sources from the internet. The data obtained were compiled, analyzed, and concluded to get a conclusion. The results of the study indicate that the development of civic virtue in the social and economic can be through social entrepreneurship. This is by the vision and mission of social entrepreneurship, namely: empowering the community and the surrounding environment with economic activities to increase the independence of citizens and social care attitudes. The first, way is through education and the development of social entrepreneurship programs in universities as the implementation of the Tri Dharma Perguruan Tinggi in the field of service. Second, through organizations and communities with models of social entrepreneurship. Thus, students or youth as agents of change can foster independence and social caring character as part of the criteria for civic virtue, which are personally and socially responsible and empower the surrounding community.
\end{abstract}

Keywords: Civic Virtue, Economic, Social, Social Entrepreneurship.

\section{INTRODUCTION}

Citizenship virtue or civic virtue is a dedication of citizens to the welfare of their community groups. Civic virtue is also defined as morality or standards of right behavior about citizen involvement in public life [1]. During the Covid-19 pandemic, we are faced with the behavior of citizens who lack virtue/civility values such as lack of independence of citizens and social care for others. Facing these problems, every citizen should put his position and be involved as a good/civilized citizen.

One of the characteristics of civic virtue awareness of disasters and the willingness to be involved in overcoming them as well as [2], the civic virtue component of the independence of citizens [3] during the Covid-19 pandemic is of course important so that citizens have a spirit of spirit that is not dependent on other people and the government, especially to meet basic needs (economy, education, and health).

However, the reality is that people's independence in Indonesia is still lacking [4] as a result there is an increase in the poverty and unemployment rates. The percentage of poor people in September 2020 was 10.19 percent. The number of poor people in September 2020 was 27.55 million people, an increase of 1.13 million. The definition of poor people here is a population with monthly per capita expenditure below the poverty line. [5].

The COVID-19 pandemic also caused a spike in the number of unemployed in 2020. There were 19.10 million people $(9.30$ percent of the working-age population) affected by Covid-19 [5].

Another problem is the number of jobs that are not proportional to job seekers. College graduates become job seekers, not job creators. This is due to the paradigm that develops in society that being a worker is safer than creating jobs [4]. As a result, there is a lack of independence and the lack of citizen involvement in community life in various fields, including efforts to improve the economy and a sense of social care for others.

To reduce the level of poverty, unemployment and improve the welfare of the community, independence and the role of the community, especially entrepreneurs, are expected to support the country's economy because the Indonesian government has limited human resources (HR) and funds for development. Community involvement in development in Indonesia is also not optimal [4]. 
One indicator of the resilience of a country's national economy can be seen from the ratio of the number of entrepreneurs 14 percent to the total population. This means that the population in the country is entrepreneurs [6]. However, the number of Indonesian entrepreneurs has only reached 3.5 percent of the total population [7]. From this data, the number of entrepreneurs is still less than the expected ratio.

Social entrepreneurship plays an important role in moving the wheels of the citizens' economy and it is hoped that civic virtue can be fostered. Increasing the independence and welfare of the community requires a social-minded entrepreneur who has a mission to empower the community and the surrounding environment to overcome social and economic problems and other problems. A social entrepreneur is a change agent who changes the business environment, looks for opportunities, improves systems, finds new approaches, and creates solutions to better environmental changes [8].

Mair and Noboa's research results show that interest in the social entrepreneurship model is specifically influenced by cognitive factors (character and morals) and individual characteristics factors (emotions and empathy), making social entrepreneurs focus on helping others [9].

Social entrepreneurship activities have been started since Muhammad Yunus founded Grameen Bank in Bangladesh pioneered the development of microcredit and social business [10]. In college, the concept of social entrepreneurship has been around for a long time and has been developed in universities, namely universities in the UK such as the Skoll Center for Social Entrepreneurship at Oxford University. The United States also established centers for the study of social entrepreneurship, for example, the Center for the Advancement of Social entrepreneurship at Duke University [11]. In Indonesia, social entrepreneurship has become a trend among the younger generation. Suyatna \& Nurhasanah's research shows that youth with various very fast and sophisticated technologies have started looking for social business opportunities as a survival option amid their narrowness in finding work [12].

The results of research conducted by the British Council (2018) have shown that there are 342,000 social entrepreneurs in Indonesia. There are three factors of interest in the world of social entrepreneurs, namely the creative industry as much as $22 \%$, agriculture and fisheries as much as $16 \%$, and in the education sector as much as $15 \%$. Business people in the social sector come from the younger generation, with an average age of 1834 years with a percentage of $67 \%$ [13].

From this background, there is a statement problem, namely how to developt civic virtue in the social and economic fields through social entrepreneurship. The purpose of this study is to examine efforts to foster civic virtue in the social and economic fields through social entrepreneurship.

\section{THEORETICAL REVIEW}

\subsection{Civic Virtue}

Bronson's theory [14] regarding the ideal competencies that good citizens must possess, namely civic knowledge, civic skills (citizenship skills), and civic dispositions (civic character). Bronson developed the existence of six pillars of character for democratic citizenship, namely: (1) Trustworthiness (2) Respect (3) Responsibility (4) Fairness (honesty), (5) Caring (6) Citizenship. From this theory, it can be seen that there is a character of virtue that is indispensable for fostering civic virtue, namely responsibility and caring.

The model from the Center for Civic Education, Civitas, United States [15] states three interrelated components, namely civic virtues, civic knowledge, and civic skills. Civic virtue consists of:

a. Civic Disposition is the attitude or habit of citizens who accept healthy social functions and guarantee the public interest in a democratic system.

b. Civic Commitment is the commitment of citizens to consciously accept the values and principles of constitutional democracy.

According to George Washington, there are four categories of civic virtue, namely civic knowledge, selfcontrol, firm attitude towards oneself, and citizen independence [2]. Bahmuller understands civic virtue as the active involvement of citizens as a form of maintaining a relationship of equality (egalitarian), mutual trust and tolerance, cooperative life, solidarity, and community spirit [16].

If we look at Article 3 of Presidential Regulation Number 87 of 2017concerning Strengthening Character Education, it is clear that there are similarities in civic virtue in it which states that PPK is implemented by applying Pancasila values in character education, especially religious values, honesty, tolerance, discipline, hard-working, creative, independent, democratic, curiosity, national spirit, love for the homeland, respect for achievement, communicative, love peace, love to read, care for the environment, care for social and be responsible [17].

Indicators civic virtue in this research are independence, cooperation, and social care.

\subsection{Social Entrepreneurship}

Social entrepreneurship as reformers, revolutionaries, and agents of change in the social sector, creates systematic change and continuous improvement. Social entrepreneurship is a behavioral orientation strategy expressed through the characteristics of innovation, proactive, risk management, electronic orientation, social mission orientation to overcome market failure and create social value [8,18-19]. Social Entrepreneurship is process and behavior-oriented, the goal is to improve social aspects and implement an integrated strategy between social and economic aspects 
so that performance can be known from the contributions made to improve social aspects. [20-21].

There are four values of social entrepreneurship, namely social values, civil society, innovation, and economic activity [21]. Opinion of Abu Saifan social entrepreneurship is a mission-driven individual who uses a set of entrepreneurial behaviors to convey social value to them the less fortunate, all through an entrepreneurially oriented entity that is financially independent, self-sufficient, or sustainable [22].

\section{METHOD}

This study uses a qualitative approach with a systematic literature review (SLR) study method. The protocol used in this SLR study is PRISMA (Preferred Reporting Items for Systematic Reviews and Metaanalyses) [23]. There are five stages used in the literature review:

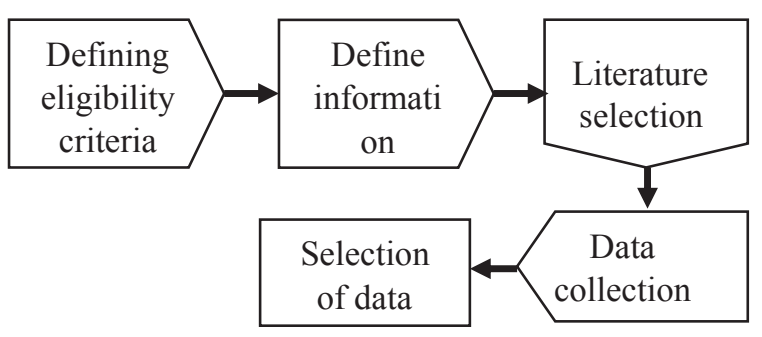

Figure 1: Flowchart of systematic literature review

The systematic literature review aims to address these issues by identifying, critically evaluating, and integrating the findings of all relevant and high-quality studies addressing one or more research questions [24]. Sources of information collected in this paper were obtained from various sources both online and offline in the from of books, journals, proceedings, dissertations, government regulations, and other sources from the internet. The systematic literature review carried out is expected to provide an overview of the development of civic virtue in the socio-economic field through social entrepreneurship. The data obtained were compiled, analyzed, and concluded to get a conclusion

\section{RESULT AND DISCUSSION}

Civic virtue cannot be forced but is carried out by a citizen voluntarily because it is an expression of freedom. The way that can be done is by teaching civic virtue or through education both formal and informal to citizens [25]. Civic virtue development in social and economic through social entrepreneurship can be carried out in the following ways, illustrated by the graph below :
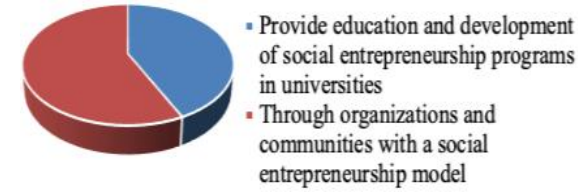

Provide education and development of social entrepreneurship programs in universities

- Through organizations and communities with a social entrepreneurship model

Graph 1. Civic virtue development in social and economic through social entrepreneurship.
That Based on the graph can explain civic virtue development in social and economic can be carried out through social entrepreneurship in two following ways:

1. Provide education and development of social entrepreneurship programs in universities as the implementation of the Tri Dharma of Higher Education in the field of service. Based on the document of the Directorate General of Higher Education of the Ministry of Education and Culture (2020) it is explained that the forms of general activities in the independent campus policy include: student exchanges, internships, teaching assistance in education units, research, humanitarian projects, entrepreneurial activities, independent projects, village building and real work lectures with the thematic concept [26].

Implementation of education and development of social entrepreneurship programs carried out at universities in Indonesia [11]:

a. FISIPOL UGM Jogjakarta: Akademi Kewirausahaan Masyarakat (AKM). Provide opportunities for scholars who have not been absorbed in the world of work to pursue social entrepreneurship

b. Indonesian Islamic University, Yogyakarta: Social Project Competition. Creating graduates who have business independence as well as social sensitivity and provide a balance of academic abilities, attitudes, and work in the context of community selfdevelopment, both as professional, independent sociopreneurs, graduates who have not been absorbed in the world of work to pursue social entrepreneurship

c. Candramuka Palembang Institute of Technology : Pusat Pengembangan Bisnis Dan Kewirausahaan Sosial (P2BKS). The academic community in the Candramuka STISIPOL Palembang environment can understand and understand the concept of social entrepreneurship.

2. Through organizations and communities with a social entrepreneurship model so that they can create patterns of thinking, attitudes, and behavior in citizens who are good, independent, responsible, socially concerned, and participate in society in all fields (civic virtue). By providing entrepreneurial competencies such as productive activities to citizens, they become effective figures in life.

Implementation organizations with mixed Social Entrepreneurship models such as Bali Recycling provide solutions related to waste management in Bali. Rumah Cemara, CD Bethesda, and Greeneration have developed various social entrepreneurs (such as food stalls, acupuncture education, and product sales), and provide services to the younger generation, as well as providing family support, child protection, fundraising, and continuous service improvement To address the problems of adolescents and marginalized children [27], Sacita Muda Indonesia Bandung, West Java is an organization that focuses on education, empowerment, and research. Starting with social institutions that aim to 
develop local products in creating prosperity and independence in the community [28] .

Social entrepreneurship model communities such as The Local Enablers community in Bandung, West Java. The Local Enablers concept is entrepreneurship development is directed to bring benefits to the social vision by promoting local values, based on local commodities, local content, local values, and local wisdom. In its implementation, it becomes a community that has a role to transmit the entrepreneurial spirit through real examples in the form of real businesses which have the impact of giving birth to a large number of Local Geniuses [29].

If we refer to Washington's opinion on civic virtue from four categories, one of the categories is that the independence of citizens is independence in the economic field. It is hoped that every citizen has the ability and is productive in economic matters. Because the democratic system will not run well without being supported by an established economy [30].

The economy can grow well if there are entrepreneurs who collaborate with the government. Entrepreneurs can prosper society because entrepreneurship can create jobs for the community and taxpayers for state income. Meanwhile, the role of the government is to regulate, provide facilities and encourage progress in the economy [31].

In improving the welfare of the community, it is necessary to have an entrepreneur with a social spirit who will foster social entrepreneurship, because in carrying out economic activities, social entrepreneurs do not only aim to seek profit but also for a social mission by empowering the surrounding community and people who are less fortunate in terms of the economy [21]. If it is related to civic virtue as the theory from Bahmuller who understands civic virtue as the active involvement of citizens as a form of maintaining a relationship of equality (egalitarian), mutual trust and tolerance, cooperative life, solidarity, and community spirit, it is clear that social entrepreneurship plays a very important role in realizing and fostering civic virtues. This can be seen from the mission of social entrepreneurship, namely empowering the community and solving social and economic problems that are process and behaviororiented with the mission and goal of increasing social and economic values and aspects so that performance can be known from the contributions made in solving social problems [8, 18-22]. Of course through his role as a good citizen.

Coupled with the nature of social entrepreneurship according to Dees are as follows [8]:

1. Achievement of the mission to create and sustain social value

2. Engage in a continuous process of innovation, adaptation, and learning

3. Act boldly in pursuit of the vision even with limited resources.

4. Demonstrate a strong sense of responsibility to the voters served and for the results created
5. Altruist. A moral attitude that holds the principle that every individual should help, serve and help others in need

To emerge entrepreneurs with a social spirit, it is necessary to have social entrepreneurship education in educational institutions. In this case, especially in universities for the development of programs as the implementation of the Tri Dharma Perguruan Tinggi. The involvement of universities in social entrepreneurship education for students will produce entrepreneurs, collaboration with industrial companies, people who are directly involved with social entrepreneurship development programs, to new models and theories born from measurable, directed, and sustainable research results [11]. In addition, it can also be through organizations and communities with social entrepreneurship models so that they can shape the mindset, attitudes, and behavior of citizens to become social entrepreneurs.

We can see this is currently becoming a trend among young people in higher education as the implementation of the service-based Tri Dharma Perguruan Tinggi, as in the opinion of Santosa, social entrepreneurship is the act of someone who understands social problems and uses entrepreneurial skills to make social change, both in the fields of welfare, education, and health [32].

\section{CONCLUSION}

Efforts to foster civic virtue in the social and economic fields can be done through social entrepreneurship. This is by the vision and mission of social entrepreneurship, namely: empowering the community and the surrounding environment with economic activities to increase the independence of citizens and social care attitudes. The first, way is through education and the development of social entrepreneurship programs in universities as the implementation of the Tri Dharma Perguruan Tinggi in the field of service. Second, through organizations and communities with models of social entrepreneurship. Thus, students or youth as agents of change can foster independence and social caring character as part of the criteria for civic virtue, which are personally and socially responsible and empower the surrounding community.

\section{REFERENCES}

[1] D.B.D. Blanken, The Good Liberal Citizen: Why Citizens can be both Free and Virtuous, Master Thesis (MSc), Leiden University, 2012

[2] F. Rahmafitria, V. Sukmayadi, K. Suryadi, \& A. Rosyidie, Disaster management in Indonesian tourist destinations: how institutional roles and community resilience are mediated. Worldwide Hospitality and Tourism Themes, 2021

[3] G. Washington, George Washington and Civic Virtue, 
https://studylib.net/doc/14500558/george-

washington-and-civic-virtue, 1993

[4] E. Saepudin. Pengembangan Ekonomi Kewarganegaraan (Economic Civic) Pada Masyarakat Demokratis, Prosiding Seminar Nasional Penguatan Komitmen Akademik Dalam Memperkokoh Jatidiri PKn. 455-456, Laboratorium Pendidikan Kewarganegaraan 4 April 2015

[5] Badan Pusat Statistik (BPS) https://www.bps.go.id/pressrelease/2021/02/15/1851/ persentase-penduduk-miskin-september-2020-naikmenjadi-10-19-persen.html.

[6] Tim Publikasi Katadata, HIPMI Siap Dongkrak Jumlah Pengusaha Baru di Indonesia, 2019 https://katadata.co.id/arsip/berita/5e9a5182aed13/hip mi-siap-dongkrak-jumlah-pengusaha-baru-diindonesia.

[7] Kementerian Koperasi dan UKM Republik Indonesia,2020

https://kemenkopukm.go.id/read/kemenkop-danukm-berharap-lulusan-perguruan-tinggi-dituntutberkarya-kreatif-dan-inovatif 2020.

[8] J.G. Dees, The Meaning of Social Entrepreneurship, White paper The Center for the Advancement of Social Entrepreneurship, Duke Fuqua University, 1998, pp. 1-5

[9] J. Mair. \& E. Noboa, The Emergence of Social Enterprises and Their Place in the New Organizational Landscape. IESE Working Paper 253, Barcelona.2003 https://core.ac.uk/download/pdf/6536275pdf

[10] M. Palesangi, Pemuda Indonesia Dan Kewirausahaan Sosial. Jurnal Posiding Seminas Competitive Advantage, Vol.1 (2), 2012, 1-6

[11] L.E. Hasanah, Pengembangan Kewirausahaan Sosial Pada Perguruan Tinggi Melalui Social Project Competition, Jurnal Studi Pemuda, Vol. 7 (2), 2018, 90-99.

DOI:http://doi.org/10.22146/studipemudaugm.4021 $\underline{0}$

[12] H. Suyatna \& Y. Nurhasanah, Sociopreneurship Sebagai Tren Karir Anak Muda, Jurnal Studi Pemuda, Vol. 6 (1), 2017, 527-537

[13] British Council. (2018). Developing an Inclusive and Creative Economy The State of Social Enterprise in Indonesia (online) https:/www.britishcouncil.org/sites/default/files/th e_state_of_social_enterprise_in_indonesia_british council_web_final_0.pdf

[14] M.S. Bronson, The Role Of Civic Education A Forthcoming Education Policy Task Force Position Paper from the Communitarian Network. Washington, DC: The George Washington
University. 1998

[15] C.N. Quigley, J.Jr. Buchanan \& C.F. Bahmueller, Civitas: A Framework for Civic Education. Calabash: Center for Civic Education. 1991

[16] C.F. Bahmueller, The Future of Democracy and Education for Teaching In Elementary Social Studies. New Jersey: Englewood Cliffs. 1996

[17] Peraturan Presiden Nomor 87 Tahun 2017 tentang Penguatan Pendidikan Karakter (PPK)

[18] A. Dwivedi \& J. Weerawardena, Conceptualizing and operationalizing the social entrepreneurship construct, Journal of Business Research 86, 2018. pp.32-40.

Doi:https://doi.org/10.1016/j.jbusres.2018.01.053.

[19] F.M. Santos, A positive theory of social entrepreneurship. Journal of Business Ethics 111(3), 2012, pp. 335-351. Doi: https://doi.org/10.1007/s10551-012-1413-4

[20] A.B. Wiguna, \& Manzilati, Social Entrepreneurship and Socio-entrepreneurship: A Study with Economic and Social Perspective, Procedia - Social and Behavioral Sciences 115, 2015, pp. 12-18

[21] L. Hulgard, Discourses of Social EntrepreneurshipVariation of The Same Theme? EMES European Research Network. 2010

[22] A.B. Saifan, Social Entrepreneurship: Defenition and Boundaries, Technology Innovation Management Review. 2012

[23] P. W. Handayani, Systematic Review dengan PRISMA (Preferred Reporting Items for Systematic Reviews and Meta-analyses), Workshop Riset Sistem Informasi Fakultas Ilmu Komputer UI. 2017

[24] A. Siddaway, What is a Systematic Literature Review How Do I Do One, dalam: A.Y. Nuryantini, W. Handayani, E.K. Yuningsih, \& H. Yuniarti, Tinjauan kurikulum dan model pembelajaran di era digital. e-book/e-journal LP2M, 40(xx), 2020, 1-7.

[25] S. Fitriasari, Pengembangan Pembelajaran Pendidikan Kewarganegaraan Berbasis "Green Constitution" Untuk Menumbuhkan Keadaban Kewarganegaraan Terhadap Lingkungan (Doctoral dissertation, Universitas Pendidikan Indonesia). 2017.

[26] Direktorat Jenderal Pendidikan Tinggi Kementerian Pendidikan dan Kebudayaan, Buku Panduan Merdeka Belajar - Kampus Merdeka. Jakarta: Kemendikbud, 2020

[27] B. Kusumasari, The Business Model of Social Entrepreneurship in Indonesia. BISNIS \& BIROKRASI: Jurnal Ilmu Administrasi dan Organisasi, 22(3), 2016, 156-168. 
[28] Sacita Muda Indonesia. Profil Sacita Muda Indonesia, Bandung-Jawa Barat. (2021).

[29] A. Bunyamin, D. Purnomo, S. Taofik, M. Nawawi. (2016). The Local Enablers: Mengusung Pemberdaya Lokal Berorientasi Global dalam Kerangka Bisnis Sosial, Prosiding Asosiasi Kewirausahaan Teknologi Indonesia Konferensi Nasional Inovasi Dan Technopreneurship 2016. 814

[30] E. Danial, Economic Civic Membina Warga Negara; Bersikap dan Berpartisipasi Dalam System Ekonomi Nasional Untuk Meningkatkan Kesejahteraan Masyarakat, Bandung: Laboratorium PKn UPI. 2007

[31] M. Astamoen, Entrepreneurship dalam perspektif kondisi bangsa Indonesia. Bandung: Alfabeta, 2005

[32] S.P. Santosa, Peran socio entreprenurship dalam pembangunan, Makalah dipaparkan dalam acara dialog "Membangun Sinergisitas Bangsa Menuju Indonesia Yang Inovatif, Inventif dan Kompetitif" diselenggarakan oleh Himpunan IESPFEUniversitas Brawijaya Malang, 14 Mei 2007 